\title{
DYNAMICS OF COSTS OF ECOSYSTEM SERVICES OF SMALL TOWNS IN KYIV REGION
}

\author{
O. Zibtseva, V. Yukhnovskyi
}

\section{Національний університет біоресурсів і природокористування України}

\begin{abstract}
Здійснено порівняння екологічного потенціалу двох рівновіддалених від Києва малих міст - Фастова і Кагарлика за загальною вартістю екосистемних послуг, отримуваних на їх територіях. Дослідні міста розташовуються у Київській височинній області лісостепової зони, мають схожу історію розвитку, але різняться за площею, кількістю мешканців і щільністю поселення, а також промисловим розвитком і структурою землекористування. Незважаючи на переваги кониепиії екосистемних послуг, їі застосування в міському плануванні стримується обмежсеністю або відсутністю даних для оцінювання. Дослідження виконано за матеріалами генеральних планів міст з використанням трансферного методу. Вартість екосистемних послуг на території дослідних малих міст розраховано за категоріями земельного фонду сільськогосподарськими угіддями, лісовими екосистемами і водними поверхнями. Екосистемні послуги з 1 га кожної категорії землекористування скориговано переведенням у долари США з урахуванням коефіцієнта переносу вартості за паритетом купівельної спроможності грошей для України. Встановлено, що загальна кількість отримуваних екосистемних послуг майже однакова для обох міст. Водночас, міста суттєво відрізняються відносною кількістю екостабілізуючих територій, що позначається на питомих показниках вартості екосистемних послуг. На одного мешкания Фастова припадає втричі менша кількість екосистемних послуг, а на одиницю площі вдвічі, й така тенденція буде збережена у перспективі. Динаміка загальної вартості екосистемних послуг на території Кагарлика свідчить про недотримання принципу екозбалансованості території у перспективному плануванні, що суперечить концепції сталого розвитку.
\end{abstract}

Ключові слова: землекористування, зелені насадження, екозбалансований розвиток.

The ecological balance of the territories of small towns is ensured by the balance of economic entities and local natural ecosystems. Nowadays, significant progress has been made in identifying, quantifying and evaluating different ecosystem services (ES), but they remain poorly implemented in urban planning [1]. Legislative uncertainty of the mechanisms of the long-term development of small towns and the inadequate use of ecosystem services as the main tool for managing the state of the urban environment exacerbates not only socio-economic but also environmental problems of the development of small towns.

The use of land is undergone dramatic changes and conflicts over demand for land and requires coherent management and responsible land use on the locally. At present, fertile land coverage is increasing with buildings, transport infrastructure and industry,

(c) O. Zibtseva, V. Yukhnovskyi, 2020 which calls for the preservation of natural resources [2].

With the strengthening of sustainable urban planning, the concept of a compact green town has become a global world ideal [3]. However, sealing processes are posed a threat to the town's green space [4], which is already problematic in compact towns [5]. Artmann et al. [6] consider it necessary to combine the concept of green infrastructure and ecosystem services with the strategic landscape planning of compact towns, as well as to introduce rules for compromises between sealing towns and providing green space. It is noted that priorities for the distribution of land in urban green spaces are neglected or easily negotiated in countries in transition [7].

Unfortunately, for most small towns, planting inventory data are absent or obsolete [8], moreover, data from different sources hava significant differences, which does not contribute to successful planning and mana- 
gement [9]. Instead, an accurate definition of the urban green space is a prerequisite for understanding its ecosystem services [10].

Ecosystem services in towns and adjacent suburban areas are one of the main factors that guarantee quality of life. Most studies relate to individual towns [11]. Determining the implications of the use of urban lands for ecosystems and the quantitative indicators of the relationship between urban land dynamics and landscape ecological stability are important for the effective formulation of urban development and environmental policies for sustainable urban development [12].

Urban ecosystem services can increase the sustainability of the city, which directly depends on the quantity, quality and diversity of the green infrastructure they produce.

The aim of the study was to carry out a comparative description of the ecological potential of the ecologically balanced development of small towns of Kyiv region in terms of ecosystem services.

\section{MATERIAL AND METHODS}

The objects of the study were two small towns - Fastiv and Kaharlyk, which are developing intensively. Their selection is made according to the criterion of availability of current (newly developed) publicly available

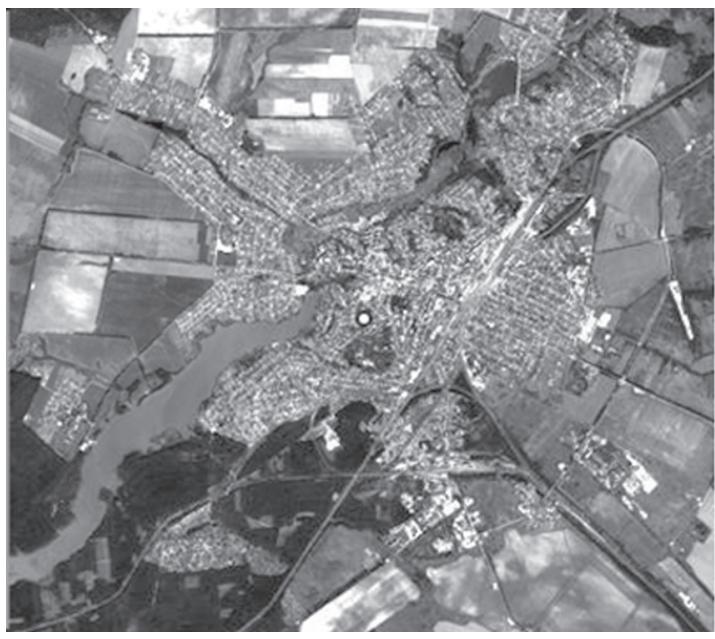

a master planning materials. This choice is justified by the lack of a population census, the inventory of urban green spaces, the availability of data on the territories of small towns and the convenience of use [13]. Both towns are geographically located on the Kyiv Plateau in the Kyiv Highland province of the ForestSteppe zone. The towns have similarities with the period of founding - respectively, 1390 and 1142 years, the distance from Kyiv (64 and $77 \mathrm{~km}$ ), but significantly vary by area and population, and therefore the density of settlement (Fig. 1, Table 1).

The town of Fastiv is an important railway hub with developed industry, which has 3.5 times more population than Kaharlyk. Both towns are territorially belonging to a zone of significant warm supply, unstable moisture.

For the territories of both towns, black soils are characteristic of loamy loam: for Fastiv they are loamy, and for Kaharlyk they are typical slight-humus. The territories of both towns cross the rivers almost in half, forming water-green diameters and green wedges. Despite the location in the Forest-steppe zone and urban planning requirements for the formation of green space, the green areas of towns are practically absent. For the outskirts of Fastiv characteristic agricultural cenosis

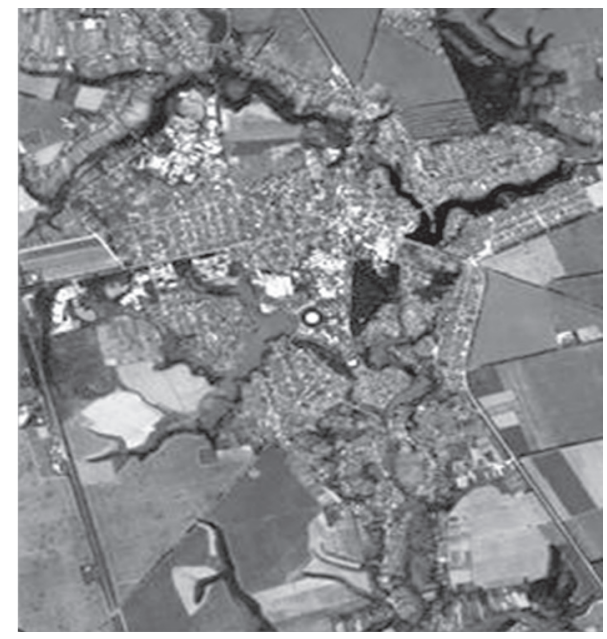

b

Territories of Fastiv (a) and Kaharlyk (b) towns according to satellite imagery on August 26, 2018 (Land Viewer EOS) in natural color 
Physical-geographical characteristics of small towns

\begin{tabular}{l|c|c|c|c|c}
\hline \multicolumn{1}{c|}{ Town } & $\begin{array}{c}\text { Year } \\
\text { of foundation }\end{array}$ & $\begin{array}{c}\text { Distance from } \\
\text { Kyiv, km }\end{array}$ & Area, ha & $\begin{array}{c}\text { Population, } \\
\text { thousand residents }\end{array}$ & $\begin{array}{c}\text { Population density, } \\
\text { persons } / \mathrm{km}^{2}\end{array}$ \\
\hline \hline Fastiv & 1390 & 64 & 4386 & 48.5 & 1105 \\
\hline Kaharlyk & 1142 & 77 & 2131 & 13.8 & 647 \\
\hline
\end{tabular}

Table 2

Economic characteristics of small towns

\begin{tabular}{l|c|c|c}
\hline \multirow{2}{*}{ Town } & \multicolumn{2}{|c|}{ Financial capacity } & \multirow{2}{*}{$\begin{array}{c}\text { Ecological } \\
\text { tax, UAH/ha }\end{array}$} \\
\cline { 2 - 3 } & UAH per person & UAH per m & 37.63 \\
\hline \hline Fastiv & 4981.71 & 5.28 & 24.51 \\
\hline Kaharlyk & 2274.07 & 1.47 & 28 \\
\hline
\end{tabular}

are in place of oak forests, and for Kaharlyk in place of meadow steppes and steppe meadows. On the territory of both towns there are parks-monuments of landscape gardening: in Fastiv - Molodizhnyi and Fastivskyi parks, in Kaharlyk - Kaharlytskyi park.

Fastiv is not only a railway hub, but also an industrial town with advanced engineering, woodworking, food production, pulp and paper industry and others. Kaharlyk has developed food production, fish farming etc. Living conditions of the population are estimated as moderately favorable for Fastiv and satisfactory - for Kaharlyk [14]. Both towns have newly developed general plans approved in 2016 and 2014, respectively. In addition, the analysis of towns was supported by publicly available data on the characteristics of small towns over the data of land management forms 6-earth (Table 2).

Data the table 2 indicate that financial capacity per person or budget revenues per unit of the town of Fastiv is 2.2 and 3.6 times higher than the similar indicators of Kaharlyk town. Similarly, the environmental tax per unit of the territory of Fastiv is 1.5 times higher than the similar indicator of Kaharlyk, which indicates more powerful harmful production in its territory.
According to the master plan of 1987, the Kaharlyk area amounted to 1517.0 hectares, and the population by 2007 would have grown to 40.0 thousand, which turned out to be too optimistic. Instead, despite almost three times lower than the planned population (13.8 thousand), the town's area has already increased in 1.4 times. The town is considered compact. From the west, the Kaharlyk area is limited to the highway of the Kyiv-Myronivka railroad and the industrial zone, the refineries of the sugar plant, from the east - the highway of the state importance of $\mathrm{H}-01$, the main gas pipeline and the transmission line, which leads to an elongated meridian-radial planning structure. Three industrial zones have been formed in the city territory, which are enclosed in the residential area, which is a significant anthropogenic load on the urban ecosystem.

To determine the value of all ecosystem services provided to locals in the studied small towns, the technique, which takes into account the types of land use [12] have already been used by us [15]. According to the method, urban lands are divided into four categories of land use: urban (built) arable land, forest and water. We have applied this technique using the cost-transfer coefficient defined by the formula [15]: 


$$
V_{t r}=V_{1} \cdot \frac{G D P_{t r}}{G D P_{1}},
$$

where $V_{\text {tr }}$ is the value of the service in the target country of study, i.e. Ukraine; $\mathrm{GDP}_{\mathrm{tr}}-$ gross national product per capita in the country of study; $\mathrm{GDP}_{1}$ is the gross national product per capita in the country where the data chosen from.

Formula 1 uses gross national income per capita in purchasing power parity in USD for 2017: China - \$16760, Ukraine - \$8900, i.e. the GDPtr / GDP1/GDP1 cost transfer ratio is 0.53 .

For comparison, the average annual cost of 1 hectare non-urban ecosystem services may be $\$ 1093-2777$ [16]. That is, our rather virtual values are comparable to data of other sources.

In connection with the distribution of urban areas for only four specified categories, in addition to the forest, the area of all urban green plantations was also attributed, and to the arable land - the area of all agricultural lands and wetlands, the rest of the territories are conventionally attributed to urban landscapes, which are ecosystem services do not provide. For both towns, the opportunity to determine the cost of ecosystem services at both the current stage and the prospective general plan was realized (by 2036).

\section{RESULTS AND DISCUSSION}

According to the current master plan, the ecological framework of the Kaharlyk town is represented by a system of green plantations, water areas and coastal protected streams of the Ros river and its tributaries. At present, the area of the park-monuments of landscape architecture of national importance «Kaharlytskyi» has decreased from 35.5 hectares (in 1980) to 29.5 hectares.

The prospective development of the town is foreseen, in particular, due to the conversion of 176.8 hectares of agricultural land, 59.5 hectares of forests, 0.7 hectares of freeof-territory land development, and the use of 99.0 hectares of land outside the city. An increase in the total area of green spaces is expected at the expense of 12.5 hectares of agricultural land, 59.5 hectares of forests (of which 7.0 hectares are suburban). Other extensions of the city square are planned at the expense of 42.9 hectares of agricultural land and 23.6 hectares of free-of-territory development (of which 46.0 hectares are suburban). The use of 5.5 hectares of agricultural land is also foreseen for the creation of special purpose green plantations.

The new general plan envisages an increase in the area of public construction more than twice: from 3.2 to $7.1 \%$ of the total area, reducing the area of agricultural land from 51.0 to $37.7 \%$, increasing the area of green spaces of common use from 100.8 to 179.8 hectares. At present, the provision of greenery is $73.0 \mathrm{~m}^{2}$ per capita, and according to the plan for 2036 it will be $112.3 \mathrm{~m}^{2}$ per capita. It should be noted that the norm of planting greenery the only straightforward normalized indicator for green public spaces - for the city is currently observed. However, since there was no inventory of greenery in the city (which is typical for Ukrainian small towns), there is no clear data on the availability of all categories of green plantings.

Tables 3 and 4 give an overview of the current and future situation regarding the cost of ecosystem services in urban research areas.

At present, $65.6 \%$ of the town's area under the built-up (eco-destabilizing) territories of the Fastiv is located, and in the long run this indicator will increase by $2.4 \%$ to $67.9 \%$. At the territory of Kaharlyk, only $33.7 \%$ of the territory is currently under building, but in the long run the indicator increase by $8.6 \%$ and will amount to $42.3 \%$.

Table 4 takes into account the perspective dynamics of the demographic situation (population increase from 48.5 to 55 thousand in Fastiv and from 13.8 to 16.0 thousand in $\mathrm{Ka}^{-}$ harlyk), as well as expansion of the Fastiv area from 4386 to 4562.5 hectares and Kaharlyk from 2130.7 to 2280 hectares by 2036 . According to calculations, the total cost of ecosystem services in the territory of Fastiv is only $5 \%$, and in the long run - by $6 \%$, the value of the total indicator for the territory of Kaharlyk, which currently has twice the area, will exceed. 
Dynamics of land categories and cost of ecosystem services in small towns

\begin{tabular}{l|c|c|c}
\hline \multirow{2}{*}{ Town, year } & \multicolumn{3}{c}{ Area, ha } \\
\cline { 2 - 4 } & Arable land & Forest & Water \\
\hline \hline Fastiv 2015 & 1199.42 & 224.66 & 85 \\
\hline Fastiv 2036 & 1019.55 & 357.62 & 85 \\
\hline Kaharlyk 2013 & 1087.70 & 237.20 & 87.6 \\
\hline Kaharlyk 2036 & 865.70 & 362.20 & 87.6 \\
\hline Cost of ES per ha & Cost of ecosystem services, USD & 3233.77 \\
\hline Fastiv 2015 & 972.38 & 1537.05 & 274870.45 \\
\hline Fastiv 2036 & 1166292.01 & 345313.65 & 274870.45 \\
\hline Kaharlyk 2013 & 991390.03 & 549679.82 & 283278.25 \\
\hline Kaharlyk 2036 & 1057657.73 & 364588.26 & 283278.25 \\
\hline
\end{tabular}

Table 4

Dynamics of ecosystem services cost sharing in small towns

\begin{tabular}{l|c|c|c}
\hline \multirow{2}{*}{ Town, year } & \multirow{2}{*}{ Total cost of EP, USD } & Cort, USD \\
\cline { 3 - 4 } & & 36.82 & Per 1 ha \\
\hline \hline Fastiv 2015 & 1786476.11 & 32.43 & 407.31 \\
\hline Fastiv 2036 & 1815940.30 & 123.59 & 398.01 \\
\hline Kaharlyk 2013 & 1705524.24 & 105.11 & 800.45 \\
\hline Kaharlyk 2036 & 1681787.13 & 0.30 & 737.62 \\
\hline Fastiv 2015 & \multicolumn{3}{|c}{ The value of ecosystem services } \\
\hline Fastiv 2036 & 1.05 & 0.26 & 0.51 \\
\hline Kaharlyk 2013 & 1.06 & 1 & 0.50 \\
\hline Kaharlyk 2036 & 1 & 0.85 & 1 \\
\hline
\end{tabular}

Data of table 4 emphasize the negative temporal dynamics of ecosystem services per capita and per unit area of both towns. The exception is only the total cost of ecosystem services in Fastiv for the future, which suggests a well-thought out development of urban areas in terms of newly developed general plan for long-term development of the town.
In terms of one hectare, the number of ecosystem services received in Fastiv, now and in the future, is twice lower than in Kaharlyk. In the long run, it decreases by 2.2 and $7.8 \%$ respectively, which suggests that, despite the decrease the cost of ecosystem services in Kaharlyk is much faster, nevertheless the town has a better planning structure from the point of view of ecological balance, where 
relatively broadly represented eco-stabilizing territories. At the same time, due to the different population density in research towns (in 1.7 times), Kaharlyk has three times more per capita, and in the long run - almost four times more valuable ecosystem services.

According to the indicators of general planning for the development of Fastiv, in the long run, the total cost of ecosystem services in its territory will increase slightly, but due to the growth of the population (by almost 7.5 thousand) the indicator per capita will decrease by $12 \%$, and by 1 ha - only on $2.2 \%$, despite the expansion of the town's area in the long run by 176.5 hectares.

In the case of implementation of the master plan for the perspective development of Kaharlyk, by 2036, the total cost of ecosystem services received from ecosystems in its territory will slightly decrease (by 1.4\%), despite the growth of the town's area by 149.3 hectares (or 7\%), which will correspond to a reduction of the cost by $8 \%$ per 1 ha of the town territory and by $15 \%$ per capita (in case of reaching the estimated prospective population -16.0 thousand).

All this testifies to the fact that, despite the declaration by the developers of the master plans for the sustainable development of urban areas, this problem has not been given sufficient attention. At present, calculations are not used that would allow modeling and controlling the eco-balanced development of urban areas. As a result, there is an expansion of the town, first of all, the built-up area, which is accompanied by a promising decrease in the cost of ecosystem services in the towns.

\section{CONCLUSIONS}

It has been found that the research towns Fastiv and Kaharlyk have similar not only geographic characteristics but also close value assessments of ecosystem services provided in their territories. However, towns differ significantly in the relative number of eco-stabilizing areas, which affects the specific indicators of the number of ecosystem services per capita and per unit of urban area. One resident of Fastiv accounted for three times less ecosystem services, and twice less per unit area. This tendency is traced to the future.

The analysis of the dynamics of the total cost of ecosystem services in the territory of the pilot towns, first of all Kaharlyk, revealed non-compliance with the ecological balance of the territory in the perspective planning of towns, which contradicts the concept of sustainable development.

It is determined that although the pilot towns are declared as compact, their area is expanded disproportionately to the demographic situation. Sustainable urban development involves preserving natural resources. However, the development of towns and, as a result, the reduction of economically stabilized lands - forest and arable land, due to which urban expansion is usually taking place, will further reduce the overall cost of ecosystem services that provide green infrastructure and relative indicators per capita and per unit of urban areas.

We consider expedient to adhere to the development of small towns in a compact scenario, and if necessary, the implementation of their socio-economic development should be foreseen at the expense of hypertrophied extensive agricultural structure. Contrary to current norms, in Kaharlyk (as in many small towns of the region) there is virtually no suburban green zone in the form of forest massive, the formation of which should be immediately focused in the near future. To increase the ecological potential of towns, the expediency of preserving forest lands and ecologically stabilizing lands is substantiated.

\section{ЛITЕРАТУРА}

1. Assessing how green space types affect ecosystem services delivery in Porto, Portugal / M. Graçaa, P. Alvesa, J. Gonçalvesa [et al.] / L Landscape and Urban Planning. - 2018. - Vol. 170. - P. 195-208.

2. A typology of urban green spaces, ecosystem services provisioning services and demands [Електро- нний ресурс] / R. Cvejić, K. Eler, M. Pintar [et al.]. - 2015. - Режим доступу: http://greensurge. eu/working-packages/wp3/files/D3.1_Typology_ of_urban_green_spaces_1_.pdf2

3. Tappert $S$. Contested urban green spaces in the compact city: The (re-) negotiation of urban gardening 
in Swiss cities / S. Tappert, T. Klöti, M. Drilling // Landscape and Urban Planning. - 2018. - Vol. 170. - P. 69-78.

4. Anguluri $R$. Role of green space in urban planning: Outlook towards smart cities / R. Anguluri, P. Narayanan // Urban Forestry \& Urban Greening. - 2017. - Vol. 25. - P. 58-65.

5. Haaland $C$. Challenges and strategies for urban green-space planning in cities undergoing densification: A review / C. Haaland, C. Van den Bosch // Urban Forestry \& Urban Greening. - 2015. - Vol. 14. P. 760-771.

6. Artmann M. Using the Concepts of Green Infrastructure and Ecosystem Services to Specify Leitbilder for Compact and Green Cities-The Example of the Landscape Plan of Dresden (Germany) / M. Artmann, O. Bastian, K. Grunewald // Sustainability. - 2017. - Vol. 9(2). - P. 198.

7. Capturing residents' values for urban green space: Mapping, analysis and guidance for practice / C. Ivesab, C. Okeac, A. Hehird [et al.]. // Landscape and Urban Planning. - 2017. - Vol. 161. - P. 32-43.

8. Большова О.Г. Проблемы и перспективы озеленения малых городов Липецкой области / О.Г. Большова, И.Л. Бухарина // Аграрный вестник Урала. - 2012. - № 9(101). - С. 59-63.

9. Challenges of urban green space management in the face of using inadequate data / M. Feltynowski, J. Kronenberg, T. Bergier [et al.]. // Urban Forestry \& Urban Greening. - 2018. - Vol. 31. - P. 56-66.

10. Dynamics of Hierarchical Urban Green Space Pa- tches and Implications for Management Policy / Z. Yu, Y. Wang, J. Deng [et al.]. // Sensors. - 2017. - Vol. 17(6). - P. 1304.

11. Szumacher I. Temporal Changes in Ecosystem Services in European Cities in the Continental Biogeographical Region in the Period from 1990-2012 / I. Szumacher, P. Pabjanek // Sustainability. - 2017 - Vol. 9. - P. 665.

12. Coupling Intensive Land Use and Landscape Ecological Security for Urban Sustainability: An Integrated Socioeconomic Data and Spatial Metrics Analysis in Hangzhou / X. City Cen, C. Wu, X. Xing, [et al.]. // Sustainability. - 2015. - Vol. 7. - P. 1459-1482.

13. Yukhnovskyi V. Dynamics of ecological stability of small towns in Kyiv region / V. Yukhnovskyi, O. Zibtseva // Journal of Geology, Geography and Geoecology. - 2018. - Vol. 27(2). - P. 386-398.

14. Комплексний атлас Київської області / [О.В. Онищак, О.Ю. Король, О.В. Радченко та ін.] - К.: ДНВП «Картографія», 2009. - 80 с.

15. Yukhnovskyi $V$. Eco-service potential of sustainable development of small towns / V. Yukhnovskyi, O. Zibtseva // Journal of Geology, Geography and Geoecology. - 2019. - Vol. 28(4). - P. 795-803.

16. Strokov A. Economical evaluation of ecosystem services in Tavushskaya oblast' of Armenia [Електронний ресурс] / A. Strokov, I. Poleshkina // Agricultural and Resource Economics: International Scientific E-Journal. - 2016. - Vol. 2. - Режим доступу: www.arejournal.com

\section{REFERENCES}

1. Graçaa, M., Alvesa, P., Gonçalvesa, J., Nowakc, D.J., Hoehnc, R., Farinha-Marquesa, P., \& Cunhab, M. (2018). Assessing how green space types affect ecosystem services delivery in Porto, Portugal. Landscape and Urban Planning, 170, 195-208 [in English].

2. Cvejić, R., Eler, K., Pintar, M., Železnikar, Š., Haase, D., Kabisch, N. \& Strohbach, M. (2015). A typology of urban green spaces, ecosystem services provisioning services and demands. greensurge.eu Retrieved from: http://greensurge.eu/working-packages/wp3/ files/D3.1_Typology_of_urban_green_spaces_1 .pdf2 [in English].

3. Tappert, S., Klöti, T. \& Drilling, M. (2018). Contested urban green spaces in the compact city: The (re-)negotiation of urban gardening in Swiss cities. Landscape and Urban Planning, 170, 69-78 [in English].

4. Anguluri, R. \& Narayanan, P. (2017). Role of green space in urban planning: Outlook towards smart cities. Urban Forestry E Urban Greening, 25, 58-65 [in English].

5. Haaland, C. \& Van den Bosch, C.K. (2015). Challenges and strategies for urban green-space planning in cities undergoing densification: A review. Urban Forestry \& Urban Greening, 14, 760-771 [in English].

6. Artmann, M., Bastian, O. \& Grunewald, K. (2017). Using the Concepts of Green Infrastructure and Eco- system Services to Specify Leitbilder for Compact and Green Cities-The Example of the Landscape Plan of Dresden (Germany). Sustainability, 9(2), 198 [in English].

7. Ivesab, C.D., Okeac, C., Hehird, A., Gordona, A., Wangd, Y. \& Bekessya, S.A. (2017). Capturing residents' values for urban green space: Mapping, analysis and guidance for practice. Landscape and Urban Planning, 161, 32-43 [in English].

8. Bolshova, O.G. \& Bukharina, I.L. (2012). Problemy i perspektivy ozeleneniya malykh gorodov Lipetskoy oblasti [Problems and prospects of landscaping small towns of the Lipetsk region]. Agrarnyy vestnik Urala - Agrarian Bulletin of the Urals, 9 (101), 59-63 [in Russian].

9. Feltynowski, M., Kronenberg, J., Bergier, T., Kabisch, N., Laszkiewicz, E. \& Strohbach, M.W. (2018). Challenges of urban green space management in the face of using inadequate data. Urban Forestry $\mathcal{E}$ Urban Greening, 31, 56-66 [in English].

10. Yu, Z., Wang, Y., Deng, J., Shen, Z., Wang, K., Zhu, J., \& Gan, M. (2017). Dynamics of Hierarchical Urban Green Space Patches and Implications for Management Policy. Sensors, 17(6), 1304 [in English].

11. Szumacher, I. \& Pabjanek, P. (2017). Temporal Changes in Ecosystem Services in European Cities in the Continental Biogeographical Region in the Period from 1990-2012. Sustainability, 9, 665 [in English]. 
12. Cen, X., Wu, C., Xing, X., Fang, M., Garang, Z. \& Wu, Y. (2015). Coupling Intensive Land Use and Landscape Ecological Security for Urban Sustainability: An Integrated Socioeconomic Data and Spatial Metrics Analysis in Hangzhou City. Sustainability, 7, 1459-1482 [in English].

13. Yukhnovskyi, V.Yu. \& Zibtseva, O.V. (2018). Dynamics of ecological stability of small towns in Kyiv region. Journal of Geology, Geography and Geoecology, 27(2), 386-398 [in English].

14. Onyshchak, O.V., Korol, O.Yu. \& Radchenko O.V. (Ed.). (2009). Kompleksnyi atlas Kyivskoi oblasti
[The complex atlas of the Kiev region]. Kyiv: DNVP «artohrafiia» [in Ukrainian].

15. Yukhnovskyi V. \& Zibtseva O. (2019). Eco-service potential of sustainable development of small towns. Journal of Geology, Geography and Geoecology. 28(4), 795-803 [in English].

16. Strokov, A. \& Poleshkina, I. (2016). Economical evaluation of ecosystem services in Tavushskaya oblast' of Armenia. Agricultural and Resource Economics: International Scientific E-Journal, [Online]. 2, 1, Retrieved from: www.arejournal.com [in English].

Стаття надійшла до редакції журналу 25.01.2020

\title{
ЕКОЛОГО-ЕКОНОМІЧНА ОЦІНКА РЕКРЕАЦІЙНО- ТУРИСТИЧНОГО ПРИРОДОКОРИСТУВАННЯ
}

\author{
O.I. Дребот, К.О. Бабікова \\ Інститут агроекології і природокористування НААН
}

Проаналізовано еколого-економічну оцінку розвитку екологічного туризму на рекреаційних територіях, а також рейтинг регіонів ресурсно-рекреаційних компонентів України. Визначено інтегральну оцінку природних рекреаційно-туристичних ресурсів України за такими природними блоками: кліматичні, рослинні, тваринні. Запропоновано етапи прийняття організаційно-управлінських рішень для забезпечення збалансованого рекреаційно-туристичного природокористування, що сприятиме невиснажливому природокористуванню та розширеному відтворенню ресурсів. У рекреаційно-туристичному господарстві одним з найважлливіших завдань є визначення та неухильне дотримання принципу еколого-економічної ефективності, що дає змогу утримувати рекреаційні зони у належному стані та забезпечити рентабельність рекреаційно-туристичного господарства.

Ключові слова: рекреаційні ресурси, рекреаційно-туристичний потенціал, природокористування, інтегральні природні ресурси, територіальна структура, туристична індустрія.

Територія України є складним і розмаїтим комплексом географічних, природно-кліматичних, гідрологічних та інших чинників, а також ресурсів тваринного та рослинного світу, унікальність сполучення яких обумовлює формування незвичайного за властивостями рекреаційно-оздоровчого потенціалу багатьох регіонів нашої країни. Значна кількість об'єктів культурної та архітектурної спадщини, музеїв та інших пам'яток, пов'язаних із видатними історичними подіями та особистостями,

(C) О.І. Дребот, К.О. Бабікова, 2020 визначає високий рівень привабливості національних туристичних маршрутів для пізнавального, розважального та пригодницького проведення дозвілля. У регіонах України сформовано також доволі потужну інфраструктуру гостинності, розміщення та обслуговування вітчизняних і зарубіжних туристів [1].

Проблема раціонального природокористування полягає в забезпеченні всебічного використання, відновлення і збереження природних умов і ресурсів рекреації із урахуванням об'єктивно існуючих потреб. Для iii розв'язання потрібно глибоко і всебічно 